2019, Vol. 05 (II) 0I-29

\title{
HR Practices: A Source of Sustainable Competitive Advantage or Competitive Parity - A Systematic Literature Review
}

\author{
G.A.S.K. Silva \\ University of Sri Jayewardenepura, Sri Lanka \\ B.N.F. Warnakulasuriya \\ University of Sri Jayewardenepura, Sri Lanka

\section{B.J.H. Arachchige} \\ University of Sri Jayewardenepura, Sri Lanka
}

\begin{abstract}
High Performance Work Practices or High Commitment Work Practices in HRM are often said to be a potential source of sustainable competitive advantage. However, some researchers have questioned that notion. Therefore, the objective of this paper is to review and analyze relevant literature to determine whether the HR practices can be considered as a real source of sustainable competitive advantage. This study followed the Systematic Literature Review method. This paper analyzes theoretical base for such claim as well as available empirical evidences and suggests that HR practices (often called as High Performance Work Practices) are more likely to be a source of competitive parity than a source of sustainable competitive advantage. The major significance of this paper is that it addresses a key question within Strategic Human Resource Management: whether HR practices can be considered as a source of sustainable competitive advantage. Further, this may be the first to discuss HR practices as a source of competitive parity. It also highlights research gaps in the area of the relationship between HRM and firm-performance.
\end{abstract}

\section{Keywords}

HR practices; Sustainable Competitive Advantage; Competitive Parity; HR and firm-performance relation; High Performance Work Practices

\section{Corresponding Author:}

Mr. Silva G A S K is a PhD candidate at the Faculty of Management Studies and Commerce, University of Sri Jayewardenepura, Sri Lanka. E-mail: phd6II5fm20I40I3@sjp.ac.lk 


\section{Introduction}

With the rapid development of the globalized economy, both practitioners and academics have identified the importance of the 'human factor' for the success of an organization (Sajeevanie, 2015). The growing acceptance of internal resources as sources of competitive advantage has given legitimacy to the assertion that Human Resource (HR) is strategically important to firm-performance (Wright et al., 2001). With this recognition, sets of HR practices that are believed to be influencing firm-performance were introduced (e.g. Freund \& Epstien, 1984; Arthur, 1994; Pfeffer, 1994; Huselid 1995; MackDuffie, 1995). These HR practices are often proclaimed as High Performance Work Practices (HPWP) or High Commitment Work Practices (HCWP).

In the recent past, a considerable attention has been drawn to HPWP (Arachchige \& Robertson, 2015). The common theoretical argument that underpins these studies is the belief that these HR practices can have a significant impact on firm-performance and thus can be a source of sustainable competitive advantage (MackDuffie, 1995; Arthur, 1992; Arthur 1994; Huselied et al., 1997). However, a contradictory conclusion was made by Park et al., (2004) based on perspectives of HR executives in Asia Pacific Region. They concluded that static set of HR practices were less like to be real sources of sustainable competitive advantage. Further, Wright et al., (2001) also questioned the belief that HR practices could be a source of sustainable competitive advantage because of the lack of empirical support and imitable nature of HR practices. Despite these arguments, SHRM researchers continuously believe that $\mathrm{HR}$ practices are a real source of sustainable competitive advantage. This disparity leads to the research question of this study; can HR practices be considered as a real source of sustainable competitive advantage? Therefore, the objective of this review is to address this question by analyzing the available literature on the relation between HR practices and firm-performance and its theoretical base.

\section{Methodology}

Procedure recommended by Tranfield et al., (2003) for Systematic Review Approach has been followed in this study as Systematic Review process increases methodological rigor and helps developing a reliable knowledge 
of the subject ( $\mathrm{Ng} \& \mathrm{Peh}, 2010)$. According to the guidelines of Tranfield et al., (2003), the Systematic Literature Review that has been followed in this study is as follows;

Step 1 - Selection of studies

Related papers were selected using keywords such as HR practices, sustainable competitive advantage, competitive parity, HR and firmperformance relation, SHRM, High Performance Work Practices and High Commitment Work Practices. Snowballing technique was also used. Search engines include Emerald Insight, Google Scholar, Taylor and Francis, and Science Direct. Figure 03 presents graphically the selection process of the articles.

\section{Figure 1: Flow-chart for identifying eligible articles}

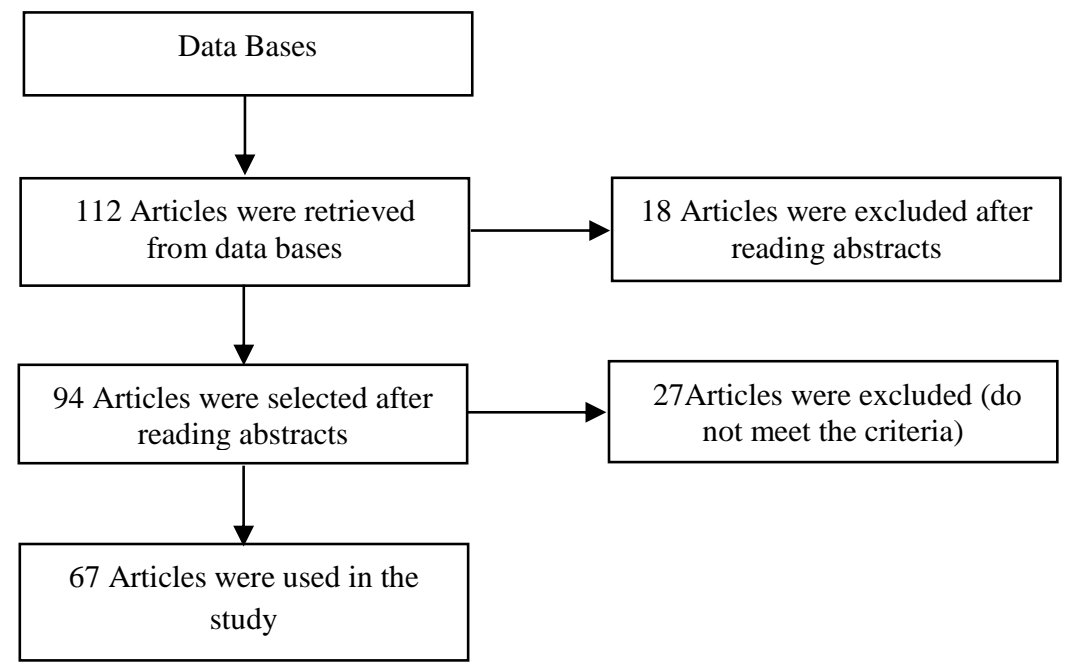

Adapted from Ng \& Peh (2010)

Sample consists of papers range from year 1985 to 2017 and an average citation per paper is 4444 . Nine papers have exceeded 10,000 citations and twenty papers have exceeded 2000 citations. Journal name and number of papers from each journal are as follows. 
Table 1: Sources

\begin{tabular}{lc}
\hline & No of \\
Journal/Source & Papers \\
\hline Journal of Management Studies & 6 \\
Academy of Management Journal & 5 \\
International Journal of Human Resource Management & 4 \\
Strategic Management Journal & 3 \\
Asia Pacific Journal of Human Resources & 2 \\
British journal of management & 2 \\
Harvard Business School Press & 2 \\
Human resource management journal & 2 \\
International Journal of Project Management & 2 \\
Management science Journal & 2 \\
Sri Lankan Journal of Human Resource Management & 2 \\
Asian Academy of Management Journal & 1 \\
California Management Review & 1 \\
Engineering, Construction and Architectural Management & 1 \\
International Journal of Business Insights and Transformation & 1 \\
Journal of Applied Psychology & 1 \\
Online Open sources & 1 \\
Books and Other sources & 19 \\
\hline
\end{tabular}

Step 2 - Quality assessment of the papers

The criteria that was used to include and exclude papers/articles are mainly the relevance to the research question and the objective of the study. Citations, methodology, authors' backgrounds and recognition of the journals were used for quality assurance. Research question has been formulated as 'can HR practices be considered as a source of sustainable competitive advantage?'

Step 3 - Data extraction

Relevant data were extracted qualitatively using extraction forms and a summary table.

Step 4 - Data synthesis

Data synthesis was performed using narrative approach. Research synthesis includes summarizing and integrating of different studies on a topic or 
research question (Mulrow, 1994 as cited in Tranfield et al., 2003). The simplest and best-known form of research synthesis is a narrative review that attempts to identify what has been written on a subject or topic (Tranfield et al., 2003, p. 217). In the process, similar ideas were combined and some were modified in order to increase the level of clarity.

Step 5 - Reporting and dissemination

A thematic analysis has been performed according to the recommended steps by Clarke and Braun (2013) to identify and organize themes. The steps followed in the thematic analysis include familiarization with the data, coding, searching for themes, reviewing themes and defining and naming themes.

Step 6 - The report and recommendations

The report starts with highlighting the background that leads to the research question for which this study has answered. The literature section has been organized under five themes: Defining HRM practices, Studies on the relationship between HRM practices and firm-performance, Resource Based view as the theoretical base, Sustainable competitive advantage and Competitive parity. Empirical evidences and theoretical arguments that lead to major arguments and conclusion have been presented in summary form in the demission section and finally conclusion and recommendations have been presented.

\section{Literature Review}

This section is aimed to achieve mainly two objectives; to discuss how the concept of HR practices, sustainable competitive advantage, competitive parity have been defined in the literature and to find out empirical support and theoretical arguments that are required to answer the key research question of this study.

\section{Defining Human Resource Management Practices}

Human Resource Management (HRM) practices are often called as HR practices. HR practices generally reflect the identifiable functions of the Department of HRM (Wright \& McMahan, 1992). HR practices of a firm 
generally include job design, job analysis, human resource planning, recruitment, selection, hiring, induction, performance evaluation, pay and incentive management, training and development, welfare management, management of employee movements, health and safety management, discipline management, grievance handling, employee and labour relations (Serasinghe \& Opatha, 2011). Typically, HRM function includes three distinct aspects: policies, procedures and practices (Serasinghe \& Opatha, 2011). Therefore, the term 'HR practices' is an umbrella term that includes all these three aspects: policies, procedures and practices. Dessler (2007) explains that the HRM functions encompass the policies and practices that are involved in efficient and effective management of the 'human resource (HR)' aspects of the organization. Noe et al., (2007) explain that HRM is about influencing employees' behaviour, attitudes, and performance through HRM policies, practices, and systems. Therefore, the ultimate aim of HR practices is to create a positive influence on employee performance.

Storey (1992, p.7) defines HRM as a "distinctive approach to employment management, which seeks to achieve competitive advantage through the strategic deployment of a highly committed and capable workforce, using an integrated array of cultural, structural and personnel techniques". The concept of HRM has been evolving and today the key challenge of HRM professionals is to ensure that the HR practices are well aligned to the overall strategy or to the objectives of the organization. Therefore, HR practices are defined as formal instruments and procedures that are used either in combination or individually to manage effectively and align employees' knowledge and activities with organizational goals and aspirations (Combs et al., 2006; Paauwe, \& Boselie, 2005 as cited in Sapegina \& Weibel, 2017). The requirement of aligning firm's HR to objectives of an organization gave rise to the concept of Strategic Human Resource Management (SHRM). Therefore, SHRM concerns how HRM is linked to objectives or overall strategy of the organization (Truss et al., 2012). Wright \& Boswell (2002) as cited in Truss et al., (2012), provide a distinction between HRM and SHRM research based on a number of HRM practice concerns (single practice vs multiple practices) and the level of analysis (individual level vs organizational level). Accordingly, SHRM research should necessarily focus on analysis of multiple HR practices at 
organizational level rather than on an individual HR practice or/and individual level analysis.

Initially, HR practices had been categorized as calculative (control) and collaborative (commitment) based HR practices. Calculative HR practices refer to the quantifiable exchange between employer and employee (e.g. performance related pay) and collaborating HR practices refer to the commitment based HR practices which aim to foster employer and employee mutual interest (e.g. strategy briefing). Gooderham et al., (2008) used another category as intermediary, which includes the practices that do not immediately fall into the said two categories (e.g. downsizing). Sapegina \& Weibel (2017) present a conceptual model as competitive HR systems (e.g. pay differences and relative incentives). In general, High Performance Work Practices (HPWP) in HRM refer to the human resource management practices that increase organizational performance (Kepes \& Delery, 2007). According to Boselie (2010), HPWP are those specific HR practices that create employee skills that ultimately lead to the improvement in organizational performance. Therefore, Eisenberger et al., (1997) explain that HPWP may increase organizational effectiveness by creating conditions where employees become highly involved in the organization and work hard to achieve its goals, in other words, by increasing their employees' commitment to the organization. Most authors have used the concept of HPWP to indicate the implication of HR practices have on performance in an organization (Munteanu, 2014).

\section{Studies on the Relationship between Human Resource Management Practices and Firm-performance}

Literature present sets of HR practices (see Appendix 1) that have been introduced by various researchers (e.g. Freund \& Epstien, 1984; Arthur, 1994; Pfeffer, 1994; Huselid, 1995; MackDuffie, 1995), that are believed to be having significant associations with firm-performance. In addition to that, Delaney \& Huselid (1996) found in a study of 590 organizations that HR practices such as selectivity in staffing, training and incentive compensation have positive associations with perceived organizational performance. Jones et al., (2010) investigated the relationship of employee involvement and financial participation to firms in the manufacturing sector. 
The results advocated that financial participation indices (particularly performance-based pay) are positively related to firm-performance whereas employee involvement does not show a significant positive association with firm-performance. Gooderham et al., (2008) conducted a large-scale investigation to find out the impact of bundles of HR practices on the firmperformance using 3,281 firms located in European Union countries. In this study, factor analysis of 80 different HRM practices resulted in 15 bundles of HRM practices which were then further categorized as either "calculative", "collaborative" or "intermediary" (see Appendix 2 for list of HR practices). Then the relationship between these HR practices and firmperformance was analyzed while controlling for contingency factors (firm strategy, firm size, market conditions and degree of unionization, as well as controlling for industry and country). The results indicate that while five of the six calculative practices and two of the three intermediary practices have a significant impact on performance, but none of the six collaborative practices has a significant impact. It was further noted that the overall effect of HRM on performance was relatively modest. Often, these well-known HR practices have been introduced based on studies conducted in large manufacturing and service sector organizations mostly located in American and European counties.

It is very difficult to find methodologically sound studies that show strong relationship between specific set of HR practices and firmperformance. However, some empirical studies indicate positive associations between some of the HR practices and firm-performance in different county contexts. For examples, Uysal \& Koca (2009) tested HR practices and firm performance relation in Turkey using the questionnaire produces by Delaney \& Huselid (1996) and the correlation analysis demonstrated that HR practices have a positive relationship with organizational performance. Fey et al., (2000) investigated the relationship between HR practices and firm-performance using 101 foreign firms operating in Russia. In this study, HR practices included individual performance-based compensation, merit-based promotion, job security, technical training, non-technical training, career planning, decentralized decision making, internal promotion, complaint resolution system and high salaries. Their model included HR outcomes (employee motivation, retention and development) as mediating variables. The results did not 
adequately support a direct relationship between HR practices and firmperformance. This study provides some support for the use of HRM outcomes as a mediating variable between HRM practices and firmperformance. The results also indicated that non-technical training and high salaries can have a positive impact on HR outcomes for managers while job security is the most important predictor of HR outcomes for non-managerial employees. In addition, results indicated a direct positive relationship between managerial promotions based on merit and firm-performance for managers and job security and performance for non-managers. Zhang \& $\mathrm{Li}$ (2009) analyzed the relationship of HPWP and firm-performance in a sample of pharmaceutical companies in China. The results indicate that the human resource management index composed of HPWP (extensive training, participation, detailed job definition, results-oriented performance appraisal, internal career opportunities, and profit sharing) were significantly related to firm's market performance.

Singh (2004) studied 82 Indian firms and found that there is a significant relationship between two human resource practices (training and compensation) and perceived organizational performance and market performance of the firm. Tregaskis et al., (2013) found in a longitudinal case study that the implementation of HPWP was associated with subsequent and sustained increases in productivity and safety performance. Subramony, (2009) conducted a meta-analysis using 65 studies on HR practices and firm-performance relation from 1995 to 2008 . This study investigates the relationship between three bundles of practices (empowerment, motivation, and skill-enhancing) and business outcomes (retention, operating performance, financial performance, and overall performance). Each bundle included sets of complementary HR practices (see Appendix 3). Findings of this study revealed that HRM bundles were positively related to business outcomes and larger magnitudes of effects than their constituent individual practices. Sapegina \& Weibel (2017) explained that strategic combination of HR practices that are based on 'complementary conceptual logic' as a bundle rather than single HR practices significantly contribute to positive organizational and employee outcomes. Absar et al., (2010) investigate the impact of HR practices (recruitment and selection, training and development, performance appraisal and compensation) on organizational 
performance in fifty manufacturing firms in Bangladesh. The results show that HR practices have significant association with organizational performance. Out of all HR practices, only performance appraisal is found to have significant impact on organizational performance.

Researchers have often attempted to identify HR practices used in particular sectors and/or their effectiveness based on perception of employees than finding the link between HRM and firm-performance in the Sri Lankan context. For examples, Mangaleswaran \& Srinivasan (2009) have attempted to identify HR practices in public sector banks in Sri Lanka. Mangaleswaran (2009) studies the HR practices used in Sri Lankan Small and Medium Enterprises and their effectiveness. In addition, there are some studies that attempted to identify the effect of HR practices on particular outcome such as productivity. For example, Navaratna et al., (2008) conducted an empirical investigation to find out the relationship between nine HR practices/functions and overall employee productivity in selected manufacturing firms in eight industrial estates of Sri Lanka. According to the findings of that study, HR planning, job analysis, recruitment and selection training, compensation and welfare and performance appraisal have positive association with overall employee productivity whereas orientation, industrial relation, and disciplinary handling show a weak correlation.

It is observable that most of these studies generally show associations between some HR practices and firm-performance. However, there is a lack of studies that demonstrates a strong/large impact of HR practices on firmperformance. Further, the nature of the empirical studies on HR practices and firm-performance, that have been discussed above is often correlational and there is a lack of casual studies (cause and effect) in this area of research. Another characteristic is that those studies have often been conducted in large functional organizations such as manufacturing and service organizations. Project oriented organizations such as construction is less reflected in the literature. Further, it is observable that studies of HRM and firm-performance relation have often been backed by the Resources Based View (RBV) of the firm. RBV provides the theoretical explanation as to why a relationship between HRM and firm-performance should exist. RBV has been widely acknowledged as the dominant theoretical framework 
within the SHRM field (Truss et al., 2012). Therefore, it is important to analyze the key assumptions of RBV in order to address the research question of this review.

\section{Resources Base View (RBV) as Theoretical Base}

In general, literature on relationship of HRM and the firm-performance can be divided into three main kinds of approaches: Universalistic, Contingency and Configurational (Gooderham et al., 2008). Therefore, studies on HR practices have used either best-practices, best-fit or configurational approaches (Arachchige and Robertson, 2015). Resource Base View (RBV) has been the key theory that legitimizes the calm that HR practices can be considered as a source of sustainable competitive advantage. RBV essentially explains and predicts the relationship between the resources of a firm and sustainable competitive advantage by performance - related outcomes (Armstrong \& Shimizu, 2007). SHRM literature is increasingly concerned on whether HR can be a source of competitive advantage (Kamoche, 1996). People of an organization are recognized as the most valuable resource, which is essential to conceive of and implement valuecreating strategy. RBV analyzes and interprets organizational resources to understand how organizations can achieve sustainable competitive advantage (Madhani, 2010). The origin and development of the RBV can be traced back to the work of Penrose (1959). Wernerfelts (1984) articulation of the RBV of the firm was the first coherent statement of the theory. Works of Rumelt \& Lamb (1984), Barney (1991) and Dierickx \& Cool (1989) have extended RBV (Dunford et al., 2001). According to the RBV, the competitive advantage and superior performance of an organization is explained by the distinctiveness of its resources capability (Johnson et al., 2008, p. 94). According to Barney (1991), the core assumptions that are important for explaining RBV are firm resource heterogeneity and firm resource immobility. Barney (1991) explains that firm resource heterogeneity refers to the non-homogeneous nature of resources across firms. Firm resources immobility refers to the inability of competing firms to obtain resources from other firms. Barney (1991) introduces four criteria (Rare, Valuable, Inimitable, and Non-substitutable) to identify strategic resources/capability that can bring sustainable competitive advantages. 
There are different classifications of resources in the strategy literature. For example, Daft (1983) explains that the firm resources include all assets, capabilities, organizational processes, firm attributes information, and knowledge etc. Grant (1991) classifies firm resources as financial resources, physical resources, human resources, technological resources, reputation and organizational resources. Barney (1991) categorizes firm resources as physical capital resources (physical technology, plant and equipment, geographic locations, access to raw material etc), human capital resources (training, experience, judgment, intelligence, relationships, insights of individual managers and workers) and organizational capital resources (formal reporting structure, formal \& informal planning, controlling and coordination systems, informal relation between groups within the organization and with external environment). Johnson et al., (2008, p. 96) categorize resources as;

- Physical Resource - e.g. machines, buildings or production capacity,

- Financial Resources - e.g capital, cash, debtors and creditors, and suppliers of money (shareholders and bankers)

- Human Resources - e.g. demographic profile, skills and knowledge of employees and other people in an organization's networks.

- Intellectual Capital - e.g. patents, brands, business systems and customer data bases

Primarily, resources can be categorized as tangible and intangible resources (Itami \& Roehl, 1987; Hall, 1992). Human resources often called as human capital refers to the combination of attributes such as knowledge, skills, attitudes and relationships formed in the minds, bodies and actions of individual in an organization (Yusoff et al., 2004). It could be noted that the term 'resources' has been used as an umbrella term. Johnson et al., (2008, p. 94) use the term capability instead of resources, and the capability refers to both resources (tangible and intangible) and competency of an organization. Figure 01 presents a matrix of capability which helps to understand strategic resources. 
Figure 2: Capability matrix

\begin{tabular}{|c|c|c|}
\hline Capability & Resources & Competency \\
\hline 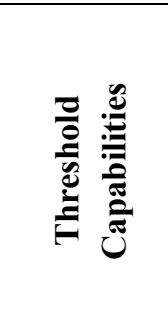 & $\begin{array}{l}\text { Threshold Resources - } \\
\text { the resources need to } \\
\text { meet customers' } \\
\text { minimum requirements } \\
\text { and therefore to continue } \\
\text { to exist } \\
\text { (Tangible or Intangible) }\end{array}$ & $\begin{array}{c}\text { Threshold } \\
\text { Competency - } \\
\text { activities and processes } \\
\text { needed to meet } \\
\text { customers' minimum } \\
\text { requirement and } \\
\text { therefore to continue to } \\
\text { exist }\end{array}$ \\
\hline 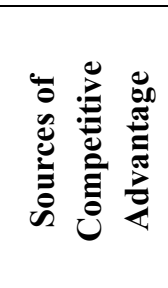 & $\begin{array}{l}\text { Unique Resources - the } \\
\text { resources that are } \\
\text { difficult for competitors } \\
\text { to imitate or obtain and } \\
\text { they underpin } \\
\text { competitive advantage } \\
\text { (Tangible or Intangible) }\end{array}$ & $\begin{array}{l}\text { Core Competency - } \\
\text { activities and process } \\
\text { that are difficult for } \\
\text { competitors to imitate or } \\
\text { obtain and they } \\
\text { underpin competitive } \\
\text { advantage }\end{array}$ \\
\hline
\end{tabular}

Source: Adopted from Johnson et al., (2008, p. 96)

The important point here is that all the resources/capabilities cannot be considered as sources of sustainable competitive advantage. As defined in Figure 01, only the unique resources and core competency of an organization have the potential to be the real sources of sustainable competitive advantage. Barney (1991) explains that only the strategic resource, which being used to conceive of and implement value-creating strategy, can be considered as sources of sustainable competitive advantage because only such resources can have the characteristics (Rare, Valuable, Inimitable, and Non-substitutable - Barney, 1991) of resources/capability that can bring sustainable competitive advantage. Therefore, it is very clear that only the unique resources and core competencies can be considered as strategic resources. According to Killen at al. (2012), the intangible resources are more likely to satisfy particularly the requirements of being rare and inimitable and such resources are more likely to be the real sources of competitive advantage. Teece et al., (1997) explain that competitive advantage rests on the firm's idiosyncratic and difficult-to-imitate resources. Purcell (1999) argues that organizations should use their resources, including intangible assets such as human resources to promote their overall model and to be better than their competitors. 


\section{Sustainable Competitive Advantage}

Theoretically, competitive advantage has been defined as superior valuecreation (Ghemawat \& Rivkin, 2006). Competitive advantage simply means a situation where a firm achieves above the average results, potentially surpassing all competitors (Spacey, 2016). Therefore, a competitive advantage means a unique advantage that leads to superior performance (Ordóñez de Pablos, 2006). Barney (1991) describes that a firm can get competitive advantage when a firm implements a value-creating strategy not simultaneously being implemented by any current or potential competitors. Brito (2014) explains that value creation does not include only the profits but it includes supplier surplus as well as customer surplus. Porter (1985) explains sustained competitive advantage as a situation where a firm yields superior performance over the long run. Therefore, sustainable competitive advantage should be understood as a situation where a firm performs better than its competitors in the areas of operation, profits (financial performance), and customer satisfaction etc for a long period. Because of a firm performing better than its competitors in all these areas it can create superior value for customers resulting in a superior performance (higher profits and market share) than its competitors for a longer period. Therefore, sustained competitive advantage exists only after efforts to replicate that advantage have ceased (Barney, 1991). This means that competitors find it very difficult or impossible to copy or buy such unique rescues and core competencies that lead to superior performance for long time. Therefore, in order to consider HR practices as a source of sustainable competitive advantage, a strong positive association between particular set of $\mathrm{HR}$ practices and firm-performance are a necessary condition. Further, such HR practices should not be able to copy or imitate immediately by its competitors.

\section{Competitive Parity}

Competitive parity is a situation where a firm achieves average or standard results when compared to others (Spacey, 2016). A firm experiences competitive parity when it is implementing a valuable strategy being simultaneously implemented by several competing firms (Mata et al., 1995, p. 489). Rowe \& Barnes (1998) explain that competitive parity is a situation where a strategy leads to normal performance and that strategy is not rare. This means that a particular strategy or resource that the company uses lead 
to average results and there is a possibility for others to imitate or acquire such resources/strategy without a great difficulty. Adepoju \& Laiyemo (2009) explain that in advertising (marketing), competitive parity method is a strategy that is used for budget allocation. Here marketing/advertising budget is set according to activities of compactors. The objective of such a method is to maintain their current position or average performance. It is very difficult to find the concept of competitive parity in SHRM research.

Identifying and developing resources with an appropriate strategy that can bring sustainable competitive advantage is a means of developing a sustainable business. Barney (1996) defines strategy as the pattern of resource and capability allocation that enables an organization to maintain or improve its performance. Resources without appropriate strategy may not give advantageous situation particularly in today's highly competitive and globalized business environment. If a particular resource or combination of resources is deployed in a particular way (strategy) that yields superior performance for a longer period, that capability (resource + strategy) can be considered as a source of sustainable competitive advantage. If that resource and strategy are producing normal/average results and the strategy is not rare, such resources can be considered as a source of competitive parity.

\section{Discussion}

The answer to the question whether HR practices can be considered as a source of sustainable competitive advantage lies in the very heart of the strategic management literature. Accordingly, only the unique resources and core-competencies (strategic resources) can have the potential to be the real sources of sustainable competitive advantage (Barney, 1991; Johnson et al., 2008). According to the capability matrix of Johnson et al., (2008, p. 94), HR practices (policies, procedures and practices - Serasinghe \& Opatha, 2011) should be difficult for competitors to imitate or obtain in order to be considered as strategic resources. In other words, HR practices should have mainly two characteristics in order to give sustainable competitive advantages. They are 'inimitability' and 'link to superior organizational performance' according to Barney (1991) and Ordóñez de Pablos (2006). When these two criteria are fulfilled, it is possible to be claimed such HR practices as a real source of sustainable competitive advantage. On the other 
hand, according to the competitive parity concept (Spacey, 2016; Mata et al., 1995; Rowe \& Barnes, 1998), HR practices that lead to average or normal performance and are imitable can be considered as source of competitive parity. According to Johnson et al., (2008) capability matrix, activities and process that lead to average or normal performance are considered as threshold performance and therefore such resources may not lead to long-term superior performance. Therefore, the characteristic of inimitability and the relationship to firm-performance are the necessary conditions that should be characterized by HR practices to be proclaimed as a source of sustainable competitive advantage or competitive parity.

Though early studies (such as Freund \& Epstien, 1984; Arthur, 1994; Pfeffer, 1994; Huselid, 1995; MackDuffie, 1995) has suggested some association between particular set of HR practices and firm-performance, it is very difficult to find out whether these studies really shows a strong longterm impact on firm-performance. Studies in the recent past (e.g. Uysal \& Koca, 2009; Jones et al., 2010; Gooderham et al., 2008; Absar et al., 2010) also indicate relatively an average impact of some HR practices on firmperformance. In general, it is difficult to find sound studies that demonstrate a set of HR practice leading to superior firm-performance. Another claim is that HR practices, as a bundle, can create a unique condition/ a unique resource (MacDuffie, 1995; Arthur, 1992), that lead to superior performance (Arthur, 1994; Huselid et al., 1997) and that competitors cannot immediately match it. This claim seams theoretically correct. However, it is difficult to find empirical support to this notion too. On the other hand, the unique condition may not merely be the result of a particular set of HR practices but it can be due to the influence of various other factors particularly, the organizational level factors such as leadership (Finkelstein \& Hambrick, 1996; Norburn \& Birley, 1988; Thomas, 1988). Lack of causal studies and methodological issues of studies in this area of research are also drawbacks. Therefore, it could be concluded that though some studies show a positive association between some sets of HR practices and firmperformance, there is no adequate empirical evidences to calm that a particular set of HR practices leads to superior firm-performance.

When applying inimitability criteria, it is clear that those HR practices cannot meet the criterion of inimitability because there aren't barriers that 
can prevent any rival organization following HR practices which are considered as good or best particularly in this knowledge era and an era of employee mobilizing is very high. Rivals are often acutely aware of one another, and this awareness influences their competitive behaviour (Bowers et al., 2014). Therefore, they quickly follow strategies (best practices) used by their competitors. Typically, within an industry (similar strategic business groups) companies often practice similar forms of HR practices or at least companies quickly follow good practices introduced by other rival companies. In general, best practices mean systems or process that a particular industry uses to manage or execute particular activity. Often these best practices are understood by doing or learning from others. Industry associations and professional bodies are well equipped with such best practices in their respective area.

As per the discussion and evidence presented, it is difficult to find empirical evidence to say that particular set of HR practices would lead to superior firm-performance over competitors. Further, HR practices that can meet the inimitability criterion are far from reality. Therefore, it could be concluded that HPWP or HCWP cannot be considered as real sources for sustainable competitive advantage. However, evidences clearly support the hypothesis that HR practices often known as HPWP or HCWP have a positive association with firm's performance and such HR practices are imitable. In that context, it is more realistic to relate HR practices to competitive parity than sustainable competitive advantage.

\section{Conclusion and Recommendation}

HR practices often known as HPWP or HCWP have been discussed in the literature as a source of sustainable competitive advantage. HR practices should have mainly two characteristics (inimitability and link to superior performance) in order to make such a claim. Though there is an association between some HR practices and firm-performance, enough empirical evidence to advocate the belief that a particular set of HR practices would lead to superior performance of business organizations are lacking. On the other hand, theoretical arguments that advocate HR practices as a resource or capability that rivals cannot imitate or copy are not convincing. Therefore, it can be concluded that considering HR practices as a source of 
sustainable competitive advantage is erroneous. However, empirical evidence and arguments that are presented in this review support the notion that HR practices (HPWP or HCWP) are related to competitive parity than competitive advantage.

It has been observed that, studies on the HRM and firm-performance relation have often been conducted in traditional functional organizations (manufacturing and service organizations) and therefore, project oriented industries, particularly the construction industry, has completely been neglected. Similar findings were reported by Huemann et al., (2006) and they stress that the literature on HRM has been framed primarily in terms of large, stable organizations, while other organizational types, such as, those relying on projects as the standard form of work design, are marginalized in discussions about what HRM is and how it should be practiced. Welbourne \& Cyr (1996) also state that much of HRM research has been conducted within larger, well-established (Fortune 500) companies. Similarly, Mangaleswaran \& Srinivasan (2009) emphasize that HR practices have been studied extensively in manufacturing and service industries. On the other hand, elevation of the profile of HRM for construction research and practice is long overdue (Dainty \& Loosemore, 2013; Wilkinson et al., 2012). Recognizing this drawback, Yong \& Musttaffa (2012) recommended giving more emphasis to improve human related factors in order to ensure successful implementation of a construction project in future. Wilkinson et al., (2012) also stress the importance of investigating HRM issues in the construction industry from both organizational performance and employee wellbeing perspectives. Silva et al., (2016) stress the need for a long-term perspective for achieving construction project success and indicate that the people factor is completely overlooked. Further, it is evident that studies on HRM and firm performance relation in the context of Sri Lanka are still inadequate. Therefore, future researchers can focus on project oriented industries, particularly on the construction industry. Also more research should be done in the Sri Lankan context as well. Further, there is a need for causal studies in order to establish the link between HRM and firmperformance.

Another drawback in this area of SHRM research is that traditionally those studies focus on HR practices in their attempt to establish how HRM 
can be source of sustainable competitive advantage. When SHRM research focuses on 'traditional HR practices' it blocks innovative ideas because SHRM researches are pre-conditioned and limited to HRM functions/practices. This limitation was identified by some researchers sometime back but still remains ambiguous. For example, Welbourne \& Cyr (1996) explained this limitation by citing Dyer \& Kochan (1994) as;

"The recent shift of the HRM field toward a more macro orientation has resulted in significant and important contributions to the field. However, as a function of the "newness" of this area of study, the work has been somewhat limited in its development of an underlying construct. Rather than considering an organizational level people management construct, to date, researchers have emphasized the activities of the HRM department. These HRM strategies or "bundles" of practices may represent something that occurs at the organizational level, or they may not. As a result, we are still not sure what strategic human resource management really represents, which leads to a number of serious problems in the areas of theory development and measurement" (p. 125).

HRM has entered to an era where it is attempting to become a "strategic partner" within the organization, helping businesses to transform and become more competitive (Welbourne \& Cyr, 1996). Given the call for HR professionals to become strategic partners (Ulrich, 1997), it is important for both practitioners and researchers in the field of HRM to understand how HR can be used as a source of sustainable competitive advantage. Therefore, it is needed to go beyond HR practices in SHRM research and focus on analyzing the relationships of organizational level HR factors/HR capabilities to firm-performance in future SHRM research. Such an approach will facilitate further development of construct underlying SHRM research and to understand how HRM really be a source of competitive advantage. Therefore, it is recommended to go beyond traditional HR practices and SHRM research should focus on Critical Success Factors of HRM that are defined as those relatively small numbers of truly important HR matters at organizational level where a particular organization should focus on, in order to achieve success. These matters should have the potential to be the real sources of sustainable competitive advantage. Silva 
et al., (2017) highlight that organizational level HR factors such as human capital, appropriate productive behaviour (Organizational Citizenship Behaviour), employer brand, organizational learning, team factor (teamcohesiveness), organizational communication and leadership factor (transformational leadership) can influence firm success particularly in the long run. These factors can be a part of the value creation process and more likely to meet the criteria for strategic resources than traditional HR practices. These factors can be developed to a level of unique HR capability. According to Wright et al., (2001), 'human capital' has greater potential to constitute a source of sustainable competitive advantage. Park et al., (2004) investigated HR practices and HR capabilities to find which one is the key organizational resource in line with RBV using HR executives in the Asia Pacific Region. Results indicate that HR capabilities are central to an organization and more likely to be a source of competitive advantage.

\section{References}

Absar, M. M. N., Nimalathasan, B., \& Jilani, M. M. A. K. (2010). Impact of HR practices on organizational performance in Bangladesh. International Journal of Business Insights and Transformation, 3(2), 15-19.

Adepoju, G. K. A., \& Laiyemo, O. O. (2009). Predictive Strategies for the Determination of Sales and Advertising Expenditures in the Pharmaceutical Industry in Nigeria. African Research Review, 3(2).

Arachchige, B. J., \& Robertson, A. (2015). The effect of human resource management high performance work practices on organizational outcomes: a Sri Lankan perspective. Sri Lankan Journal of Human Resource Management, 5(1).

Armstrong, C. E., \& Shimizu, K. (2007). A review of approaches to empirical research on the resource-based view of the firm. Journal of management, 33(6), 959-986.

Arthur, J. B. (1994). Effects of human resource systems on manufacturing performance and turnover. Academy of Management journal,37(3), 670-687.

Barney, J. (1991). Firm resources and sustained competitive advantage. Journal of management, 17(1), 99-120.

Barney, J. B. (1996). The resource-based theory of the firm. Organization science, 7(5), 469-469. 
Boselie, P. (2010). Strategic human resource management: A balanced approach. Tata McGraw-Hill Education.

Bowers, A. H., Greve, H. R., Mitsuhashi, H., \& Baum, J. A. (2014). Competitive parity, status disparity, and mutual forbearance: Securities analysts' competition for investor attention. Academy of Management Journal, 57(1), 38-62.

Brito, R. P. D., \& Brito, L. A. L. (2014). Dynamics of competition and survival. BAR-Brazilian Administration Review, 11(1), 64-85.

Cheong Yong, Y., \& Emma Mustaffa, N. (2012). Analysis of factors critical to construction project success in Malaysia. Engineering, Construction and Architectural Management, 19(5), 543-556.

Daft, R. L. (1983). Learning the craft of organizational research. Academy of Management Review, 8(4), 539-546.

Dainty, A., \& Loosemore, M. (Eds.). (2013). Human resource management in construction: critical perspectives. Routledge. [Online]. Available from. https://books.google.lk. [Accessed October 2016]

Delaney, J. T., \& Huselid, M. A. (1996). The impact of human resource management practices on perceptions of organizational performance. Academy of Management journal, 39(4), 949-969.

Dessler, G. (2007). Human Resource Management. Prentice Hall of India Private Limited, New Delhi.

Dierickx, I., \& Cool, K. (1989). Asset stock accumulation and sustainability of competitive advantage. Management science, 35(12), 1504-1511.

Dunford, B., Snell, S. A., \& Wright, P. (2001). Human resources and the resource based view of the firm. CAHRS Working Paper Series. pp. 6672

Dyer, L., \& Kochan, T. A. (1994). Is there a new HRM? Contemporary evidence and future directions. CAHRS Working Paper Series, 246.

Eisenberger, R., Cummings, J., Armeli, S., \& Lynch, P. (1997). Perceived organizational support, discretionary treatment, and job satisfaction. Journal of applied psychology, 82(5), 812.

Fey, C. F., Björkman, I., \& Pavlovskaya, A. (2000). The effect of human resource management practices on firm performance in Russia. International Journal of Human Resource Management, 11(1), $1-18$. 
Freund, W. C., \& Epstein, E. (1984). People and productivity: The New York Stock Exchange guide to financial incentives and the quality of work life. Irwin Professional Publishing.

Ghemawat, P., \& Rivkin, J. W. (1998). Creating competitive advantage. [Online]. Available from. https://www.hbs.edu/faculty/Pages/item.aspx?num=24224

Gooderham, P., Parry, E., \& Ringdal, K. (2008). The impact of bundles of strategic human resource management practices on the performance of European firms. The International Journal of Human Resource Management, 19(11), 2041-2056.

Grant, R. M. (1999). The resource-based theory of competitive advantage: implications for strategy formulation. In Knowledge and strategy (pp. 323).

Hall, R. (1992). The strategic analysis of intangible resources. Strategic management journal, 13(2), 135-144.

Huemann, M., Keegan, A., \& Turner, J. R. (2007). Human resource management in the project-oriented company: A review. International Journal of Project Management, 25(3), 315-323.

Huselid, M. A. (1995). The impact of human resource management practices on turnover, productivity, and corporate financial performance. Academy of management journal, 38(3), 635-672.

Itami, H., \& Roehl, T. W. (1987). Mobilizing invisible assets, Harvard University Press. Cambridge, MA.

Johnson, G., Scholes, K., \& Whittington, R. (2008). Exploring corporate strategy: text \& cases. Pearson education. [Online]. Available from https://s3.amazonaws.com/

Jones, D. C., Kalmi, P., Kato, T., \& Mäkinen, M. (2010). HRM practices and firm performance: Evidence from finish manufacturing. [Online]. Available from. https://aaltodoc.aalto.fi

Kamoche, K. (1996). Strategic human resource management within a resource-capability view of the firm. Journal of Management studies, 33(2), 213-233.

Kepes, S., \& Delery, J. E. (2007). HRM systems and the problem of internal fit. Oxford Handbook of Human Resource Management, The, 385.

Killen, C. P., Jugdev, K., Drouin, N., \& Petit, Y. (2012). Advancing project and portfolio management research: Applying strategic management theories. International Journal of Project Management, 30(5), 525-538. 
MacDuffie, J. P. (1995). Human resource bundles and manufacturing performance: Organizational logic and flexible production systems in the world auto industry. ILR Review, 48(2), 197-221.

Madhani, P. M. (2010). Resource based view (RBV) of competitive advantage: an overview. [Online]. Available from https://www.researchgate.net

Mangaleswaran, T., \& Srinivasan, P. T. (2009). Human Resource Management Practices in Sri Lankan and Indian Public Sector Banks: An Empirical Comparison. [Online]. Available from https. http://hdl.handle.net

Mata, F. J., Fuerst, W. L., \& Barney, J. B. (1995). Information technology and sustained competitive advantage: A resource-based analysis. MIS quarterly, 487-505.

Munteanu, A. (2014). What Means High Performance Work Practices for Human Resources in an organization. Annals of the University of Petrosani, Economics, 14(1), 243-250.

Ng, K. H., \& Peh, W. C. G. (2010). Effective Medical Writing. Singapore Med J, 51(5), 362-366.

Noe, R. A., Hollenbeck, J. R., Gerhart, B., \& Wright, P. M. (2007). Human resource management: Gaining a competitive advantage. McGraw-Hill, USA

Ordóñez de Pablos, P. (2006). Transnational corporations and strategic challenges: An analysis of knowledge flows and competitive advantage. The Learning Organization, 13(6), 544-559.

Park, H. J., Gardner, T. M., \& Wright, P. M. (2004). HR practices or HR capabilities: Which matters? Insights from the Asia Pacific region. Asia Pacific Journal of Human Resources, 42(3), 260-273.

Penrose, E., \& Penrose, E. T. (2009). The Theory of the Growth of the Firm. Oxford university press.

Pfeffer, J. (1994). Competitive advantage through people. California Management Review, 36(2), pp. 09-21.

Porter, M. E. (1985). Competitive advantage: creating and sustaining superior performance. 1985. New York: FreePress, 43, 214.

Purcell, J. (1999). Best practice and best fit: chimera or cul-de-sac?. Human resource management journal, 9(3), 26-41. 
Rowe, W. G., \& Barnes, J. G. (1998). Relationship marketing and sustained competitive advantage. Journal of Market-Focused Management, 2(3), 281-297.

Rumelt, R. P., \& Lamb, R. (1984). Competitive strategic management. Toward a Strategic Theory of the Firm, 556-570.

Sajeevanie, T. L. (2015). Strategic Human Resource Management and Theoretical Background; A Critical Review Perspective. Proceedings of the Third Asia-Pacific Conference on Global Business, Economics, Finance and Banking (APISSingapore Conference), 17-19 July 2015.

Saunders, M., Lewis P., \& Thornhill (2007). Research Methods for Business Studies. $5^{\text {th }}$ Ed. Pearson Education Limited, England. 58-59.

Serasinghe, D. S., \& Opatha, H. H. D. N. P. (2011). Human resource management practices in listed firms in Sri Lanka. Sri Lankan Journal of Human Resource Management, 1(1).

Silva, G.A.S.K., Warnakulasooriya, B.N.F. \& Arachchige, B.J. (2016). Criteria for Construction Project Success: A Literature Review. In 13th International Conference on Business Management (ICBM). University of Sri Jayewardenepura. Sri Lanka.

Silva, G.A.S.K., Warnakulasooriya, B.N.F. \& Arachchige, B.J. (2016). Theoretical Framework for Critical Human Resource Management Factors and Construction Project Success Linkage. Proceedings of International Conference (ICIRSTM-2017) NUS Singapore 16-17 September, 2017, ISBN: 978-93-5281-535-7

Singh, K. (2004). Impact of HR practices on perceived firm performance in India. Asia Pacific Journal of Human Resources, 42(3), 301-317.

Spacey, J. (2016). Competitive parity vs competitive advantages. [Online] Available: https://simplicable.com/new/competitive-parity-vscompetitive-advantage

Storey, J. (1992). Developments in the management of human resources: an analytical review. Blackwell.

Subramony, M. (2009). A meta-analytic investigation of the relationship between HRM bundles and firm performance. Human resource management, 48(5), 745-768.

Teece, D. J., Pisano, G., \& Shuen, A. (1997). Dynamic capabilities and strategic management. Strategic management journal, 18(7), 509-533.

The Navaratne, N. N. J., Silva, G. R. P., Atapattu, A. W. M. M., \& Wijayawardena, K. D. T. K. (2008). Effects of Human Resource 
Practices On Labor Productivity: A Case Of Selected Industrial Estates In Sri Lanka.

Tranfield, D., Denyer, D., \& Smart, P. (2003). Towards a methodology for developing evidence-informed management knowledge by means of systematic review. British journal of management, 14(3), 207-222.

Tregaskis, O., Daniels, K., Glover, L., Butler, P., \& Meyer, M. (2013). High performance work practices and firm performance: A longitudinal case study. British Journal of Management, 24(2), 225-244.

Truss, C., \& Gratton, L. (1994). Strategic human resource management: A conceptual approach. International Journal of Human Resource Management, 5(3), 663-686.

Truss, C., Mankin, D., \& Kelliher, C. (2012). Strategic human resource management. Oxford University Press.

Ulrich, D. (1997). Human resource champions: The next agenda for adding value to HR practices. Harvard Business School Press, Boston, MA.

Uysal, G., \& Koca, G. (2009). HR and firm performance at companies in Turkey: Correlative analysis. Journal of Modern Accounting and Auditing, 5(1), 45.

Welbourne, T. M., \& Cyr, L. A. (1996). Agency theory implications for strategic human resource management: Effects of CEO ownership, administrative HRM, and incentive alignment on firm performance. [Online] Available: https://digitalcommons.ilr.cornell.edu

Wernerfelt, B. (1984). A resource-based view of the firm. Strategic management journal, 5(2), 171-180.

Wilkinson, A., Johnstone, S., \& Townsend, K. (2012). Changing patterns of human resource management in construction. Construction Management and economics, 30(7), 507-512.

Wright, P. M., \& Boswell, W. R. (2002). Desegregating HRM: A review and synthesis of micro and macro human resource management research. Journal of management, 28(3), 247-276.

Wright, P. M., \& McMahan, G. C. (1992). Theoretical perspectives for strategic human resource management. Journal of management, 18(2), 295-320.

Wright, P. M., Dunford, B. B., \& Snell, S. A. (2001). Human resources and the resource based view of the firm. Journal of management, 27(6), 701-721. 
Yusoff, W. F. W., Jantan, M., \& Ibrahim, D. N. (2004). The interactive effects of human capital, structural capital and social capital on firm performance. Asian Academy of Management Journal, 9(2), 1-18.

Zhang, Y. C., \& Li, S. L. (2009). High performance work practices and firm performance: evidence from the pharmaceutical industry in China. The International Journal of Human Resource Management, 20(11), 23312348. 


\section{Appendices}

\section{Appendix 01: List of HR Practices}

\begin{tabular}{|c|c|}
\hline $\begin{array}{l}\text { Freund and Epstien, } \\
1984\end{array}$ & $\begin{array}{l}\text { Job enlargement, Job rotation, job design, formal training, } \\
\text { personalized work hours, suggestion systems, quality } \\
\text { circles, salary for blue collar workers, attitude surveys, } \\
\text { production teams, labour management committees, group } \\
\text { productivity incentives, profit sharing, stock purchase plan }\end{array}$ \\
\hline Arthur, 1994 & $\begin{array}{l}\text { Broadly defined jobs, employee participation, formal } \\
\text { dispute resolution, information sharing, highly skill } \\
\text { workers, self-manage teams, extensive skill training, } \\
\text { extensive benefits, high wages, salaried workers, stock } \\
\text { ownership }\end{array}$ \\
\hline Pfeffer, 1994 & $\begin{array}{l}\text { Employee security, selective recruiting, high wages, } \\
\text { incentive compensation, employee ownership, information } \\
\text { sharing, employee participation, empowerment, job } \\
\text { redesign, training and skill development, cross utilization, } \\
\text { cross training, symbolic egalitarianism, wage comparison, } \\
\text { promotion from within }\end{array}$ \\
\hline Huselid, 1995 & $\begin{array}{l}\text { Personnel selection, performance appraisal, incentive } \\
\text { compensation, job design, grievance procedure, } \\
\text { information sharing, attitude assessment, } \\
\text { labour/management participation, recruitment intensity, } \\
\text { training intensity, training hours, promotion criteria } \\
\text { (seniority vs merit) }\end{array}$ \\
\hline MackDuffie, 1995 & $\begin{array}{l}\text { Work teams, problem solving groups, employee } \\
\text { suggestions, job rotations, decentralization, recruitment } \\
\text { and hiring, contingent compensation, status } \\
\text { differentiations, training new employees, training } \\
\text { experienced employees }\end{array}$ \\
\hline
\end{tabular}




\section{Appendix 2: HR bundles and their individual HR practices}

\section{Calculative bundles}

1. Training monitoring

2. Share-options

3. Evaluation of HR Dept.

4. Profit-sharing

5. Group-bonus

6. Performance related pay

\section{Collaborative bundles}

7. Joint HR-Mgt

8. Communication on strategy

9. Communication on finance

10. Employee involvement

11. Communication on organization of work

12. Communication to management

\section{Intermediary bundles}
13. Career development
14. Wider-jobs
15. Downsizing methods

\section{Appendix 3: HR bundles and their individual HR practices Empowerment-Enhancing Bundles}

1. Employee involvement in influencing work process/outcomes

2. Formal grievance procedure and complaint resolution systems

3. Job enrichment (skill flexibility, job variety, responsibility)

4. Self-managed or autonomous work groups

5. Employee participation in decision making

6. Systems to encourage feedback from employees

\section{Motivation-Enhancing Bundles}

7. Formal performance appraisal process

8. Incentive plans (bonuses, profi t-sharing, gain-sharing plans)

9. Linking pay to performance

10. Opportunities for internal career mobility and promotions 
11. Health care and other employee benefits

\section{Skill-Enhancing Bundles}

12. Job descriptions/requirements generated through job analysis

13. Job-based skill training

14. Recruiting to ensure availability of large applicant pools

15. Structured and validated tools/procedures for personnel selection 